\title{
Leituras de Santiago a partir da crítica cinematográfica
}

Luiz Antonio Mousinho Magalhães ${ }^{1}$ e Suéllen Rodrigues Ramos da Silva ${ }^{2}$

${ }_{1}^{1}$ Luiz Antonio Mousinho é professor Associado III do Departamento de Comunicação e da Pós-graduação em Letras da Universidade Federal da Paraíba

- UFPB. Desenvolve pesquisa junto ao CNPq (PQ) sobre leitura e recepção de ficção audiovisual. e-mail: Imousinho@yahoo.com.br.

2 Suéllen Rodrigues é doutoranda vinculada ao Programa de Pós-graduação em Letras - PPGL, pela Universidade Federal da Paraíba - UFPB, bolsista CAPES/DS.

Desenvolve o projeto de tese Elena, Ofélia e A pequena sereia: arquétipos femininos trágicos e leituras da recepção crítica. É Mestre em Letras, tendo defendido a dissertação Artur e Santiago: relações entre jornalismo narrativo e cinema-documentário (PPGL/UFPB). É bacharel em Comunicação Social, habilitação em Jornalismo (UFPB, 2007). Atualmente, faz parte do Grupo de

Pesquisa sobre Ficção e Produção de Sentido. e-mail: suellenrodrigues.rs@gmail.com. 


\title{
Resumo
}

Neste artigo, observamos de que modo indivíduos da chamada "audiência especializada" reagem à complexidade narrativa do documentário Santiago (2007), de João Moreira Salles, e como interpretam, discutem e retratam as escolhas do realizador na concepção do referido texto fílmico. Para tanto, analisamos dez textos de crítica cinematográfica, nos quais os críticos partem do documentário enquanto relato para a realização de uma leitura centrada, aparentemente, com foco na identificação temática. Vistos em conjunto, tais textos, entretanto, podem ser um auxílio para o aprofundamento de reflexões sobre o filme de Salles, e o próprio gênero documental, isto no tocante a dados como a opção pelo uso da narração e questões relativas ao personagem em produções do cinema de não-ficção. A compilação de críticas apresenta também uma diferenciação não só de juízos de valor sobre a obra, mas em nível de aprofundamento, linguagem, extensão e público para o qual são direcionadas.

Palavras-chave: Santiago, crítica cinematográfica, cinema, documentário.

\section{Abstract}

In this article, we have observed how individuals of the called "specialized audience" react to the narrative complexity of the documentary Santiago (2007), by João Moreira Salles, and how they interpret, discuss and depict the choices of the director of that filmic text. Therefore, we have analyzed ten texts on film criticism, in which critics depart from the documentary while a report genre for the realization of a reading focused apparently on the identification issue. Taken together, these texts, however, can be an aid to further reflections on Salles' film, and the documentary genre itself, with respect to this data as the option for the use of narration and questions concerning the character of nonfiction film. The compilation of criticism also features a differentiation not only of value judgments about the work, but in deepening level, language, range and audience for whom they are directed to.
\end{abstract}

Keywords: Santiago, film criticism, cinema, documentary. 


\title{
Introdução
}

\begin{abstract}
Já tentei olhar bem de perto o rosto de uma pessoa - uma bilheteria de cinema. Para saber do segredo de sua vida. Inútil. A outra pessoa é um enigma. E seus olhos são de estátua: cegos.
\end{abstract}

Clarice Lispector

Em seus estudos sobre Capitu, microssérie de Luiz Fernando Carvalho (2008, TV Globo), o pesquisador Renato Luiz Pucci Jr. (2012) discute motivações para os satisfatórios índices de audiência alcançados pela produção. Após destacar que ela apresenta "uma sucessão interminável de excentricidades narrativas", o autor afirma que "segundo antigos pressupostos da crítica, o público estaria aquém desse tipo de sofisticação narrativa, acessível, dizem, apenas ao espectador de cinema, inteiramente concentrado no filme que Ihe é exibido" (PUCCI JR., 2012: 30-31).

O autor rebate a visão inicial, atribuída, por ele, à crítica audiovisual, apontando a presença de elementos de origem televisiva, com os quais os espectadores tiveram contato e assimilaram, de forma fragmentária e gradual, a partir de produções anteriores. A principal questão posta por Pucci Jr. - se os telespectadores estariam "preparados" para Capitu -, bem como sua menção à existência de pressupostos críticos que não acompanhariam as inovações de determinada produção audiovisual, são pontos de partida que nos permitem refletir a respeito de outros trabalhos também dotados de "sofisticação narrativa" e que requerem do espectador esquemas cognitivos mais elaborados do que os necessários diante de produções que se utilizam da narrativa clássica.

Na narrativa clássica, as técnicas empregadas são subordinadas à clareza, à homogeneidade, à linearidade, à coerência da narrativa. Assim, "o encadeamento das cenas e das sequências se desenvolve de acordo com uma dinâmica de causas e efeitos clara e progressiva" e o desenvolvimento "leva o espectador as respostas às questões (e, eventualmente, enigmas) colocadas pelo filme" (VANOYE; GOLIOT-LÉTÉ, 1994: 27). Dentre obras de maior complexidade narrativa, destacamos o documentário Santiago, de João Moreira Salles (2007). 
Apesar de não se tratar de uma produção televisiva, conforme Capitu, objeto estudado por Pucci Jr., consideramos interessante pensar a recepção de Santiago, com resultados positivos de público e crítica, levando em conta o que apontam Consuelo Lins e Cláudia Mesquita (2011: 12): o exagero na afirmação de que os filmes de não-ficção conquistaram um mercado sólido no país, pois "o público dos longas documentais brasileiros dificilmente ultrapassa a faixa dos 20 mil espectadores", havendo poucas exceções - dentre as quais, o filme de Salles, que superou, em 2007, a marca de 50 mil espectadores.

Será a partir da leitura de textos de crítica cinematográfica que observaremos de que maneira indivíduos da chamada "audiência especializada" interpretam, discutem, retratam e, portanto, reagem às escolhas narrativas do documentarista na concepção do referido texto fílmico, e procuraremos também discutir aspectos da própria fatura fílmica ou da própria economia narrativa da obra.

Fernando Mascarello (2006) alerta-nos para o restrito interesse pela recepção nos estudos brasileiros de cinema, em contraste com a abordagem de outras temáticas da área ou, por exemplo, em comparação às pesquisas sobre as produções para televisão, na qual o estudo das audiências tornou-se tradicional nas últimas décadas. $O$ autor destaca a deficiência no âmbito acadêmico para a pesquisa de espectatorialidade cinematográfica em atingir o "público espectador concreto" enquanto objeto das pesquisas de recepção, devido, inclusive, às dificuldades metodológicas para registrar e analisar as reações do público em sua interação com o texto fílmico.

Quando se refere ao "espectador concreto", Mascarello (2001: 9) alude ao sujeito produtor de sentidos a partir de "sua relação com o elemento contextual, ou, mais especificamente, ao trânsito por vários discursos presentes no contexto sócio-histórico". De acordo com o pensamento de Robert Stam, levamos em conta que a "história do cinema [...] é não apenas a história dos filmes e cineastas, mas também a história dos sucessivos sentidos que os públicos têm atribuído ao cinema" (STAM, 2003: 257).

Partindo de estudos sobre a teoria da leitura, Mahomed Bamba (2012: 253) refere-se ao "espectador implícito ou programado pelo texto fílmico". Segundo o 
autor, no "duplo processo de produção textual que ocorre simultaneamente 'no espaço da realização' fílmica e 'no espaço da leitura', isto é, no espaço da recepção fílmica propriamente dita", "todas as leituras são possíveis e o espectador goza de uma relativa autonomia: ele pode aceitar o jogo que o texto Ihe propõe, como também empreender outro tipo de atividade". Bamba, no entanto, destaca ser "a partir dos modos de organização do discurso narrativo que os teóricos da pragmática do cinema procuram apreender as lógicas dos usos, das leituras e das interpretações das obras fílmicas".

Partindo das pesquisas de Daniel Dayan, Bamba (2012: 254) detalha melhor o conceito, mencionando "o jogo das imagens e dos pontos de vista, que desde os níveis da enunciação da história, estrutura e programa um sujeito participante a um leque de atitudes" que, "mesmo aberto a variações individuais [...], pela mediação de 'espectadores ficcionais' que o filme, às vezes, representa e figura as condições de recepção efetiva".

A ideia de "espectador implícito ou programado pelo texto fílmico" ajuda-nos a compreender melhor as colocações de Pucci Jr. (2012) a respeito da "sofisticação narrativa" que iria pressupor esquemas cognitivos mais elaborados do que os necessários diante de produções que se utilizam da narrativa clássica, considerando, portanto, o que seria um conhecimento prévio que se infere sobre hábitos de espectação do público comum e a ideação dos sujeitos que terão contato com o filme.

No caso de Santiago, esses esquemas que fugiriam à recepção das produções clássicas do cinema documental são requeridos por ser uma obra que vai de encontro à compreensão ingênua do gênero, segundo a qual não haveria, por exemplo, espaço para a encenação, apenas um registro mais referencial do real. O filme de Salles evidencia-se como constructo, é ao mesmo tempo verborrágico e tecido por silêncios, adota diversos procedimentos estéticos e narrativos, que serão referidos em nossa análise e observados nas críticas, enquanto fruto de uma liberdade criativa de seus realizadores.

Para Bamba (2012: 254), "tanto no filme de ficção como no documentário, a recepção 'programada' não transforma o espectador em 'zombie'. Ao contrário, 
ao induzir nele um leque de atitudes bastante reduzidas [...] o filme propõe ao espectador" reações sobre o filme. "Parte dessas reações toma, às vezes, a forma de um discurso sobre o filme. A recepção fílmica que se completa por uma 'comunicação estética' consiste basicamente na transformação da fruição fílmica numa rede de manifestações verbais".

Conforme afirma Robert Stam (2003: 255), tomando por apoio a teoria da recepção e especialmente o pensamento de Wolfgang Iser, a interação entre o leitor e um texto virtual precisa ser concretizada no plano da leitura, havendo assim um espectador "agora entendido como mais ativo e crítico, não o objeto passivo da 'interpretação', mas a um só tempo constituidor do texto e por ele constituído", considerando-se que "nem o texto nem o espectador são entidades estáticas, pré-constituídas; os espectadores moldam a experiência cinematográfica e são por ela moldados, em um processo dialógico infinito" (2003: 256).

Neste estudo, não focamos o espectador comum. Voltamos nosso olhar para examinar escritos, que consideramos como registros indiciais de espectação, produzidos por indivíduos que se propõem a analisar criticamente a produção cinematográfica e, independente do lugar social que ocupam e do vínculo com os espaços midiáticos, também são "espectadores concretos".

Manuela Penafria (2009: 5), após discorrer sobre a importância da análise, defende que a escrita sobre cinema pode até "depender das competências do analista e do seu olhar particular lançado sobre os filmes desde que o mesmo tenha por detrás uma actividade de suporte sólido - a análise - e que essa actividade seja $\circ$ ponto de partida para a criação de conceitos que possam substituir a adjetivação".

Para este estudo, tomamos como base dez textos de crítica cinematográfica, contemplando publicações online de grandes veículos de comunicação (Folha de S.Paulo/llustrada, Estadão/Blog Luiz Zanin - Cinema, cultura \& afins, UOL/Revista Trópico, Globo.com/DocBlog e Críticos); revistas eletrônicas especializadas (Contracampo, Cinética, Filmes Polvo); além dos sites Cineweb, que se define enquanto produtor de conteúdo de cinema, inclusive, para agências de notícias e 
portais, como o UOL Cinema e a agência Reuters Brasil, e Overmundo, canal colaborativo sobre a cultura brasileira, criado em 2006.

André Bazin (1991: 7) sugere que "a função do crítico não é trazer numa bandeja de prata uma verdade que não existe, mas prolongar o máximo possível, na inteligência e na sensibilidade dos que o leem, o impacto da obra de arte". O conjunto de textos críticos sobre o filme aponta "determinado aspecto da sua recepção e interpretação", olhares construídos a serem percebidos como "traços interpretativos" (JOLY, 2002: 12). O estudo destes textos pode ajudar-nos a compreender aspectos que determinam futuras valorações sobre o filme.

As críticas são índices de recepção concreta sobre o documentário e desnudam procedimentos fílmicos, mecanismos de produção de sentido enquanto "intenção das obras" que observamos filtrados "pela leitura e pela interpretação, ou seja, pela intenção do leitor" (JOLY, 2002: 10), dos leitores do texto fílmico, no caso, os críticos que assinam os textos selecionados. Esclarecendo melhor, Martine Joly (2002: 10) parte de conceitos de Umberto Eco sobre a abordagem interpretativa, que seriam "a intenção do autor, ou seja, aquilo que o autor 'quis dizer', a intenção da obra, isto é, aquilo que a obra nos 'diz', e a intenção do leitor, ou seja, aquilo que este privilegiou no texto". Os textos críticos nos possibilitam ter acesso a índices das três dimensões mencionadas pela autora.

Estes profissionais, potencialmente, possuiriam maiores condições de produzir uma avaliação do que um espectador comum, pela formação, com predomínio nas áreas de comunicação social e cinema, repertório adquirido a partir do interesse pela área e tempo de experiência no exercício da crítica cinematográfica - alguns, inclusive, atuando na pesquisa acadêmica em cinema e mesmo exercendo funções diversas enquanto realizadores.

Apesar disso, o nível de aprofundamento e o modo de abordagem dos textos variam consideravelmente, o que creditamos, em parte, à lógica dos próprios veículos nos quais as críticas foram publicadas, tornando-se, portanto, necessário considerar as condições de produção do texto e as diferentes formas de contato dos críticos com o documentário. A escrita logo após a espectação, durante o 
lançamento, em uma sessão coletiva, por vezes, em única exibição nos festivais, difere em condições de realizar uma leitura mais densa, tempo de reflexão e distanciamento em relação ao objeto fílmico analisado, de uma crítica escrita a partir do material já em DVD, com a possibilidade de rever trechos que o crítico considere importantes, congelar a imagem, ter acesso a extras e a diversas visões já em circulação sobre o documentário.

Os textos críticos identificados com data de veiculação possuem vínculo cronológico com a exibição de Santiago em festivais ou com a ocasião em que o documentário entrou em cartaz nas salas de cinema, revelando critérios de agendamento e observância da atualidade para definição de pauta. $O$ texto de caráter mais imediato, produzido principalmente para os grandes meios de comunicação, atenderia a uma demanda de cunho mais informacional sobre a obra recém-lançada, ofertando um primeiro olhar sobre ela. Dentre as críticas selecionadas, aquelas que não possuem registro de data de publicação foram extraídas das revistas eletrônicas. Essas desfrutam de maior liberdade na definição dos assuntos e produções que irão abordar.

\section{Diferentes possibilidades de leitura}

De acordo com Penafria (2009: 2), "a crítica tem como objetivo avaliar, ou seja, atribuir um juízo de valor a um determinado filme em relação a um determinado fim (o seu contributo para a discussão de um determinado tema, a sua cinematografia, a sua beleza, a sua verdade...)". No conjunto de textos selecionados, o julgamento a respeito de Santiago é predominantemente positivo. Enquanto contraponto, destaca-se a avaliação negativa de Daniel Caetano ${ }^{3}$ (s/d, Revista Contracampo), que, entretanto, não deixa de admitir o mérito do documentário por este instigar impressões e posicionamentos.

Diante das peculiaridades do documentário de Salles, já, desde o título,

\footnotetext{
${ }^{3}$ Daniel Caetano é doutor em literatura brasileira, professor, já atuou como realizador na produção e direção de documentários, curtas e longas-metragens, e colaborou em algumas revistas de cinema, a exemplo da Contracampo, na qual localizamos a crítica analisada.
} 
indicando uma produção que se proporia a apresentar a história de vida de uma pessoa existente no mundo histórico, a discussão crítica tem rendimento a partir da observação sobre a função do personagem documentado. No entanto, vemos por meio dos textos críticos o quanto Santiago é, antes de tudo, um documentário sobre o próprio gênero, "uma reflexão sobre o material bruto", como apontado em seu subtítulo.

Luiz Zanin Oricchio ${ }^{4}$ (2007, O Estado de São Paulo) afirma que o filme: "reflete, no fundo, sobre o próprio cinema documental - o que 'documentamos', afinal? Algo que esteja fora da ficção? Onde está o concreto, o 'real', atrás do qual vivemos escavando, feito tatus da memória?". Para Carlos Alberto Mattos ${ }^{5}$ (2007, DocBlog), "Santiago, o filme, é um perfil enredante e uma corajosa tomada de posição sobre a função do documentarista". Retomando o assunto no site Críticos, meses depois, destaca as potencialidades do gênero: "antigamente, pensava-se que o documentário tinha por função básica oferecer respostas. Santiago, assim como o Jogo de cena, de Coutinho, nos mostra que o doc vive mesmo é de perguntas" (MATTOS, 2007b).

Thiago Camelo ${ }^{6}$ (2006, Overmundo) relata a mudança de postura de Salles não apenas entre as filmagens, feitas em 1992, e a montagem do documentário, em

\footnotetext{
${ }^{4}$ Luiz Zanin tem formação em filosofia e psicologia, pós-graduação em psicanálise, é crítico de cinema, repórter e colunista, autor de livros da área de cinema, já atuou em diversos jornais e revistas, escrevendo atualmente para o Estadão, no blog Cinema, cultura \& afins, do qual extraímos a crítica analisada.

${ }^{5}$ Carlos Alberto Mattos é crítico de cinema desde 1978, jornalista, autor de livros sobre cineastas brasileiros, tendo escrito para a Tribuna da Imprensa, Isto É, O Pasquim, Jornal do Brasil, Estadão, O Globo, e para sites, como o Críticos.com, e blogs, a exemplo do DocBlog, especializado em documentários, sendo estes últimos as fontes das duas críticas selecionadas para a análise. Na faixa comentada do filme Santiago, que consta nos extras do DVD, Carlos Alberto Mattos entrevista João Moreira Salles, Lívia Serpa e Eduardo Escorel, discutindo o documentário cena a cena.

${ }^{6}$ Thiago Camelo tem formação em jornalismo e cinema, é autor de livro de poemas, tendo atuado em algumas publicações jornalísticas, bem como o Overmundo, no qual localizamos a crítica selecionada, site colaborativo que se propõe a reunir material produzido por brasileiros sobre a cultura, especialmente o que não receberia espaço nos grandes meios de comunicação.
} 
2005, mas na trajetória recente do documentarista. O crítico menciona Entreatos (2004), documentário produzido pelo diretor sobre os bastidores da campanha eleitoral de Lula, em 2002, e recorda a não utilização de imagens de cobertura, trilha ou refilmagem de qualquer cena, o que representava uma ortodoxia ${ }^{7}$ que, afirma Camelo, não era gratuita: "o diretor aprendeu com os anos que o documentário, além de tratar do objeto, deve pensar também o próprio fazer cinematográfico".

João Moreira Salles possui uma filmografia que abarca diferentes linguagens documentais e novos procedimentos a cada filme, uma forma de explorar possibilidades do gênero e, deste modo, compreender melhor o próprio documentário. Além de Entreatos e Santiago, Salles dirigiu séries de programas para televisão, curtas e os longas-metragens Notícias de uma guerra particular (1999) e Nelson Freire (2003).

Notícias, com codireção de Kátia Lund, tornou Salles conhecido como documentarista e tematiza a violência urbana na cidade do Rio de Janeiro. Diferencia-se das propostas fílmicas posteriores do diretor, que declara discordar da visão corrente sobre o documentário enquanto espaço para denúncia e transformação social, enfatizando a ideia da produção documental como instrumento para a transformação do próprio gênero, sendo não "uma consequência do tema, mas uma forma de se relacionar com o tema" (SALLES, 2005: 65):

Durante muito tempo pensou-se que o documentário teria utilidades. Infelizmente, esta é uma ideia que ainda não caiu inteiramente em desuso, e para muita gente o filme não-ficcional deve desempenhar um papel social, político ou pedagógico. Documentário teria usos. Talvez, mas meu argumento é que não conseguimos definir o gênero pelos seus deveres para fora, mas por suas obrigações para dentro. Não é o que se pode fazer com o mundo. É o que não se pode fazer com o personagem. (SALLES, 2005: 71).

${ }^{7}$ O termo ortodoxia é referido aqui no sentido do gesto de evitarem-se, terminantemente, em produções esteticamente mais ambiciosas, recursos de linguagem desgastados, como o tradicional uso da voz over. 
Tanto a busca pelos limites da linguagem documental quanto sua preocupação sobre o modo de lidar com o personagem são perceptíveis em Santiago. Um documentário autorreflexivo, ensaístico, no qual observamos a relação de Salles com Santiago Badariotti Merlo, ex-mordomo da família Moreira Salles, desde a gravação da entrevista base para o filme, quando ficamos sabendo de sua percepção sobre a impossibilidade de concluir o filme em 1992, até termos acesso à montagem final, treze anos depois, quando as escolhas do diretor para a estruturação narrativa revelam não apenas a relação entre documentarista e documentado, mas a mudança de postura de Salles, que propõe uma nova relação com o seu personagem, trazendo as condições do encontro com ele para dentro do filme e dando-lhe voz, algo que não fazia parte do projeto inicial.

Um documentário peculiar inclusive para o diretor, devido ao seu envolvimento pessoal com a obra, que chegou a dizer não desejar dirigir novos filmes após Santiago, a não ser que conseguisse realizar outro documentário "intransferível", marcado em sua própria vivência ${ }^{8}$. Ainda durante a produção de Santiago, Salles começa a dedicar-se à revista Piauí, projeto também na concepção de narrativas não ficcionais, mas no âmbito jornalístico, passando a atuar em produções documentais fílmicas apenas como produtor e roteirista.

João Moreira Salles voltou a dirigir este ano, na conclusão do documentário Últimas conversas (2015), após o falecimento de Eduardo Coutinho, que conduzia o projeto do filme. Pelo vínculo existente entre Salles e Coutinho, de afeição, admiração e trabalho colaborativo, é um segundo filme que ocuparia na carreira do diretor um espaço bastante particular, reunindo traços que se revelam no modo como a narrativa fílmica é construída, com Coutinho posto na tela não apenas enquanto o documentarista que filma o encontro com seus personagens,

${ }^{8}$ Informações extraídas de entrevista realizada para o projeto Visões do documentário, promovido pela Casa do Saber e a Matizar Filmes, abordando o tema $O$ documentário em busca de personagens, gravada em 08 de setembro de 2008. Disponível em: $<$ http://www.youtube.com/watch?v=K3MNDWUtMSI\&list=PL72672E51FFE5CC18>. Acesso em: 2 jun. 2013. 
mas que, enquanto personagem, também fala de si, refletindo sobre o fazer fílmico e sobre a própria vida.

Retornando ao texto de Thiago Camelo, observamos de que modo ele aponta as diferenças presentes em Santiago, em questões como o uso do off (mais precisamente, voz over), considerado "coisa do passado"; da trilha; e mesmo "brincadeiras de edição", que revelam o abandono do modelo de produção documental seguido no filme de 2004. Em um dos fragmentos de entrevista que compõem a crítica de Camelo (2006), Salles comenta a nova postura adotada:

Quis fazer um filme sem ortodoxia. Quem realmente disse que não pode colocar trilha? Se acho uma música bonita, por que não posso colocar? O filme não tem imposição. Vale tudo! Acabaram as regras. Tudo o que eu tentei eliminar em Entreatos pus aqui. A única coisa que eu não queria era ser convencional. $\mathrm{E}$ isso, acho que consegui. Acho que o filme realmente apresenta alguma proposta nova.

Nas inovações propostas por Salles, também repousa a "sofisticação narrativa", no sentido utilizado por Pucci Jr. (2012), aspecto que parece ter sua importância reconhecida no campo cinematográfico. Conforme relato de Mattos (2007b, Críticos): "o filme tem sido motivo de comentários, textos, ansiedades e (já!) influências. Jean-Claude Bernardet o incluiu entre seus 'filmes-faróis' do doc contemporâneo. Kiko Goifman não nega o parentesco na trama do seu Filmefobia".

Alguns elementos dessa "nova proposta" de produção documental são referidos pela crítica, mas em uma abordagem sem ênfase ao fato de tais recursos proporcionarem novas experiências de espectação fílmica, algo que, certamente, está entre os elementos que garantem ao documentário maior complexidade. A dança das mãos de Santiago, com os movimentos enquadrados em close up na execução de uma coreografia ao ritmo de duas músicas instrumentais, é mencionada em alguns textos apenas como elemento de caracterização do personagem-título e não enquanto recurso que denotaria a liberdade criativa dos 
realizadores ${ }^{9}$.

O mesmo ocorre em relação à sequência na qual o narrador conta uma história da infância de Salles - ocasião em que este, ao levantar-se de madrugada e ouvir uma música, encontra Santiago ao piano, tocando Beethoven e usando um fraque em sinal de respeito. A sequência é citada em algumas críticas, mas, novamente, apenas enquanto artifício de caracterização do ex-mordomo, sem referência à opção peculiar do diretor pela composição apenas com imagens dos espaços da Casa da Gávea percorridos por Salles, ainda menino, cômodo a cômodo, até a chegada ao salão de festas.

Captadas anos depois de a casa ser desocupada, vemos na tela imagens de ambientes vazios, e não há encenação ou registro documental das ações. Espaços vazios que, no entanto, conforme é perceptível na espectação fílmica, estão repletos de memórias e possuem grande representatividade para os personagens da narrativa, tanto para Santiago quanto para Salles. Seria, inclusive, o retorno à casa, uma das motivações para a produção do documentário, de acordo com trecho da narração:

[NARRADOR] Saí da casa da Gávea no início da minha juventude. Sem que eu percebesse, era a primeira grande mudança, o fim da infância e da adolescência, o início de outra coisa. Mais tarde e aos poucos, a juventude foi ficando para trás. Tive vontade de voltar à casa, e por isso retomei o filme. Gostaria que essa história fosse de meus pais e também de meus irmãos, Pedro, Walter e Fernando. A memória de Santiago e da Casa da Gávea é nossa.

Percebe-se, portanto, uma lacuna nas críticas na abordagem de alguns recursos pouco convencionais. Cabe registrar a ausência de comentários sobre a inclusão, logo após menção feita por Santiago em trecho de entrevista, do áudio da ópera O barbeiro de Sevilha, na voz de Lily Pons, durante cerca de quarenta

\footnotetext{
${ }^{9}$ Liberdade possível, especialmente, por se tratar de um projeto bastante pessoal de Salles, não havendo, na revisita às imagens de 1992, uma obrigatoriedade de transformá-las em filme, amarras relativas a tempo de produção, determinação, a priori, da duração do documentário ou quaisquer reservas à experimentação. Tal questão é referida pelos realizadores de Santiago na faixa comentada do DVD, lançado em 2009.
} 
segundos, período em que a tela permanece totalmente escura, favorecendo a experiência auditiva e a fruição do espectador.

O uso da voz over, mencionado por Thiago Camelo (2006) como inovação, não é uma questão posta pelos demais críticos a partir desta perspectiva. O conteúdo do texto narrado, devido às diversas questões que suscita, e outras peculiaridades que o envolvem, é um dos elementos fortes do documentário, e cabe-nos observar como isto é trabalhado nas críticas selecionadas.

\section{A narração}

A entrevista concedida pelos realizadores de Santiago, João Moreira Salles, Eduardo Escorel e Lívia Serpa, a Carlos Alberto Mattos, disponível enquanto faixa comentada do DVD, lançado em 2009, traz informações importantes para a reflexão sobre o processo de produção que resultou em um documentário tão singular.

Uma delas é a opção pelo uso da narração, que funciona como fio condutor de todo o documentário. O diretor revela que em 1992 não considerava a possibilidade de utilizar o recurso por ser um dogma - e poderíamos compreender que a posição chamada de dogmática seria o estabelecimento de uma recusa a priori do recurso da narração em voz over, dada à sua automatização, ao seu desgaste e ao engessamento estabelecido historicamente.

De acordo com Consuelo Lins (2007), a utilização desse elemento estético nos documentários é creditada ao movimento liderado por John Grierson, na década de 1930, e esteve presente de forma intensa nas produções brasileiras até o final dos anos 1980, sendo abandonada nas últimas décadas em troca da ênfase nas entrevistas, no diálogo entre o documentarista e o seu personagem.

A rejeição à utilização do recurso justifica-se, segundo a autora, pelo fato de a narração representar uma interferência demasiada na relação filme-espectador, sendo capaz de direcionar sentidos e interpretações. Lins (2007: 10) ressalta ainda a presença de documentários brasileiros à margem da produção corrente, a partir dos anos de 1970, nos quais "a intervenção dos cineastas na relação com os 
objetos é central e explícita" e, mais recentemente, "filmes ligados à chamada produção subjetiva ou performática que adquirem mais claramente características ensaísticas". Dentre os documentários mencionados, a autora cita Santiago, afirmando que tais produções têm recuperado a narração em off e fabricado "associações inauditas do espaço sonoro do cinema com o espaço visual".

A narração em voz over, em primeira pessoa, cuja identidade, na diegese, é de João Moreira Salles, é feita por seu irmão Fernando Moreira Salles, e representa um dentre tantos elementos metaficcionais presentes no documentário, mencionado em diversos textos. Sendo, sobretudo, autorreflexiva, a narração enfatiza a necessidade de desconfiar de tudo o que é dito, de suspeitar do que está na tela, jogando com as noções de real e ficcional, verdade e mentira, desde a abertura do filme, conforme destaca Thiago Camelo (2006):

\footnotetext{
Não faltam cenas que explicitam esta dicotomia. O filme já começa assim: imagem se aproximando de um retrato, lentamente, música emocionante tocando, câmera se aproximando... Entra off: "Este seria o primeiro plano do meu filme...". O mais curioso é que o off surge quando - é o que diz quem estava na exibição - já se está envolvido com a cena. É um soco para fora da tela, como quem avisa: Viu como é fácil te emocionar? As autocríticas e auto-ironias continuam. Há a cena da folha caindo na piscina em sucessivos planos e o narrador entregando que por ali, provavelmente, havia uma mão ajudando o suposto vento e provocando aquele acaso.
}

Essa posição assumida pelo narrador, aparentemente desmascarando todas as camadas de construção do documentário, resulta na aderência do espectador ao seu discurso, tomando-o como verdadeiro. Contudo, apesar de sua característica de desnudamento, há momentos em que a narração desafia a criticidade do espectador. Um exemplo é esta colocação do narrador a respeito do personagem-título: "[NARRADOR] Essa é a última filmagem que fiz com Santiago. Ela me permite fazer uma observação final. Não existem planos fechados nesse filme, nenhum close de rosto. Ele está sempre distante" (grifo nosso). Tal discurso é reproduzido em duas críticas selecionadas, destacando-se 
o texto escrito por Leonardo $\operatorname{Amaral}^{10}$ (s/d, Filmes Polvo):

Como o próprio documentarista deixa claro no final, o filme não possui planos fechados no rosto de Santiago - há apenas um plano detalhe em que o movimento das mãos de Santiago é filmado como se ele estivesse tocando castanholas, numa espécie de balé conduzido por essas mesmas mãos.

Cléber Eduardo ${ }^{11}(\mathrm{~s} / \mathrm{d}$, Cinética) também se refere à ausência de close ups. Apesar de limitar-se a mencionar os momentos de entrevista, não faz qualquer ponderação ao uso de tal recurso em outro momento do filme, e assim reforça o discurso do narrador. Eis o que diz o crítico: "lá pelo final, quando fala da opção pelos enquadramentos mais abertos, distantes do entrevistado, sem sequer um close up, João Moreira, por meio da voz do irmão, constata o x da questão".

Essa é uma das "mentiras da narração", segundo aponta Salles na faixa comentada do DVD, que pode ser confirmada ao assistirmos atentamente à sequência da montagem de 1992, na qual uma imagem contraria a afirmação do narrador.

Com duração de apenas três segundos, e localizando-se no início da projeção, aos oito minutos e meio, quando o narrador anuncia o que seria "a única sequência que sobrou da montagem de 92", o único momento de close up de rosto de Santiago dificilmente é registrado pelo espectador. Além do curto tempo de tela, a noção de distanciamento entre documentarista e personagem documentado, referida na narração, mantém-se em todo o filme por meio dos enquadramentos usados nas entrevistas, nas quais, de fato, não há close ups de

\footnotetext{
${ }^{10}$ Leonardo Amaral é crítico de cinema e realizador, tendo assinado a direção de curtas e longasmetragens. Possui formação em nível de pós-graduação em Comunicação Social e colaborações em outras revistas especializadas em cinema, além da Filmes Polvo, para a qual escreveu a crítica sobre Santiago, na qual informa que o filme foi visto na $2^{\mathrm{a}}$ Mostra de Cinema de Ouro Preto.

${ }^{11}$ Cléber Eduardo é crítico de cinema, colaborador de jornais e revistas, dentre elas a Cinética, da qual foi editor e retiramos o texto em análise. Possui pós-graduação em ciências da comunicação, sendo professor de disciplinas teóricas e práticas de cinema, com ênfase em documentário e cinema brasileiro, curador da Mostra de Cinema de Tiradentes, tendo atuação também como diretor, roteirista e montador.
} 
Santiago, considerando o material aproveitado na montagem.

É interessante não haver qualquer menção ao aproveitamento dessa imagem e ao contraste com o que é dito em voz over, afinal, o uso de recursos metaficcionais, os elementos ambíguos contidos no filme e as possíveis contradições são tratados pela crítica a partir de outras perspectivas. Considerando, especificamente, essa ocorrência, registramos que a ratificação da fala do narrador, sem a devida problematização, aproxima, aqui, tal percepção à de um espectador comum, o que é compreensível pela brevidade da imagem em tela, em especial, no caso das espectações em sessões únicas, em festivais.

Cléber Eduardo (s/d) aborda a narração também enquanto recurso de mediação, afirmando que ela "estabelece uma distância entre nós, o diretor e o teor autobiográfico das palavras - que, apesar de narradas em primeira pessoa, são terceirizadas ao se usar como narrador a dicção formal e fúnebre de um irmão (Fernando)". Em trecho posterior, menciona elementos que também seriam responsáveis por "terceirizar" o discurso do documentarista, como as imagens de outros filmes e as lembranças da Casa da Gávea por intermédio de Santiago. O crítico então discorre sobre a mediação a partir das intermediações em algumas cenas:

Nos primeiros planos de Santiago, de João Moreira Salles, o quadro enquadra outro quadro, no caso fotografias, com elementos bem dispostos no espaço, composições de equilíbrio na melancolia, das quais "o olho do filme", e conseqüentemente do espectador, aproxima-se com um suave zoom in. É dessa maneira mediada, por meio de uma imagem de um espaço (e não do espaço), que nos instalamos em Santiago. (EDUARDO, s/d).

Para llana Feldman ${ }^{12}$ (s/d, Trópico), "a questão da mediação, porém, não é apenas temática, aquilo através do que ou de quem o filme se expressaria, mas a

\footnotetext{
12 llana Feldman é doutora em ciências da comunicação (2012), atualmente realiza pós-doutorado e já atuou como professora na área de cinema. O documentário Santiago, analisado em sua crítica publicada na revista Trópico, uma das publicações para a qual colabora, é um dos objetos de sua tese denominada Jogos de cena: ensaios sobre o documentário brasileiro contemporâneo.
} 
condição mesma de sua própria linguagem". Em certa medida, a própria mediação é central: "Não seria mais então Salles, o indivíduo biografável, o protagonista de Santiago, mas a própria lente mediadora que ele estabelece entre suas memórias, seu passado e sua imaginação".

Os recursos descritos pelos críticos no âmbito da mediação relacionam-se à metaficção. Santiago é um documentário intensamente autorreflexivo, que, como observa Feldman (s/d), tem sua metaficcionalidade construída por meio do material que seria descartado: "se Santiago nos apresenta tantas camadas, ele o faz incorporando seus restos, suas sobras, suas bordas, aquilo que no filme original estaria de fora, aquilo que ele não mais é".

Leonardo Amaral (s/d, Filmes Polvo) aprofunda a questão, comentando uma das cenas finais do documentário que revelaria, "de maneira fortuita", uma tentativa de aproximação de Santiago em relação a Salles, e não entraria na montagem de 1992 por representar uma espécie de "quebra de barreira entre documentarista e pessoa retratada". Amaral menciona o crítico André Bazin, e defende que "aquilo que 'teoricamente' seria o não mostrado é na realidade (sem trocadilhos) uma representatividade ainda maior do real", destacando que o fato de a cena estar na versão final do filme, devido à nova perspectiva adotada pelo diretor, pode ser uma representação de que nem tudo de Santiago havia sido retratado.

Tal reflexão é condizente com o pensamento de Salles (2005: 67-68), expresso em texto teórico no qual ressalta que "para o espectador o filme representa tudo; para o diretor é uma redução da complexidade, uma diminuição da experiência ou a construção de uma outra experiência - a pessoa, cada vez mais distante, cede lugar a algo próximo, o personagem". Isso nos conduz ao pensamento de outros críticos sobre o papel que Santiago desempenha no filme e faz pensar sobre uma das possíveis motivações de Salles para ter tornado-se personagem de seu próprio filme. 


\section{Santiago, Salles e um encontro entre personagens}

O fato de Santiago ser realmente sobre o personagem-título ou utilizá-lo apenas como pretexto é um dos pontos mais discutidos pela crítica. Daniel Caetano (s/d, Contracampo) é o mais enfático sobre a questão ao afirmar que:

O personagem-título acaba se tornando um pouco aquilo que Hitchcock chamava de mcguffin, uma trama que parece ser central e na verdade serve apenas para entreter enquanto outra trama se constrói como num filme em que um casal persegue uma maleta para ao fim sabermos que a trama não é sobre a maleta, e sim sobre o casal e a maleta é então um mcguffin. ${ }^{13}$

O crítico chega a discutir a opção do diretor em restringir-se ao uso das imagens de Santiago captadas treze anos antes, e não buscar outras memórias do mordomo, como suas raízes fora do país, vizinhos no Leblon ou outras fontes, ressaltando que "Santiago, o filme, satisfaz-se com o material pretensamente 'insatisfatório' de 1992".

Cléber Eduardo (s/d) alega que o documentarista usa "um filme sobre as lembranças de um ex-mordomo de seus pais, Santiago, para abrir as portas de sua casa e de seu passado". Inácio Araújo ${ }^{14}$ (Folha de S. Paulo) ratifica tal ideia desde o título de sua crítica: "Salles usa mordomo como espelho e faz um ótimo filme sobre si mesmo".

Contudo, em outros textos, encontramos tal nível de detalhamento na caracterização do personagem-título (unindo informações do que é possível captar em seus depoimentos e em suas aparições na tela com dados extraídos das falas do narrador), que nos distanciamos da ideia de mcguffin lançada por

\footnotetext{
${ }^{13}$ Consideramos bastante positiva a explanação feita por Daniel Caetano no tocante ao significado da palavra mcguffin, pautando-se em exemplos claros que facilitam a compreensão do leitor e contribuem para a sua formação.

${ }^{14}$ Inácio Araújo, crítico de cinema do jornal Folha de S. Paulo (veículo do qual extraímos a crítica analisada, publicada no período de lançamento do filme), é autor de livros da área de cinema, de romances, e possui conhecimento prático enquanto realizador, pois foi montador, assistente de direção e montagem em várias produções durante as décadas de 1970 e 1980.
} 
Daniel Caetano (s/d). Neusa Barbosa ${ }^{15}$ (2007, Cineweb) e Leonardo Amaral (s/d) estão entre esses críticos - no entanto, destacamos as visões expressas em críticas que dedicam mais espaço à caracterização de Santiago. A primeira é de Thiago Camelo (2006):

\begin{abstract}
"O tempo não tem consideração". Um argentino com nome de capital sul-americana escreveu isso certa vez. Foi Santiago. Santiago Badariotti Merlo (para ser mais preciso) era um ser absolutamente fascinante, detentor de um conhecimento único sobre dinastias e aristocracias de todo o mundo. Aliás, a sua paixão era justamente escrever sobre as grandes famílias, aquelas que, para ele, tinham algo de especial, um quê divino, uma fantasia de castelos, riqueza, luxo e cultura. Porque o que tinha de mais caro era a sua cultura. Não escondia isso, dizia-se inclusive assustado e se perguntava por que nascera tão interessado em línguas, em música, em cinema, em tudo, quase. Podia variar do erudito ao prosaico num minuto, sabia tocar Beethoven (o que fazia questão de fazer vestindo um fraque - "É Beethoven", dizia ele), mas não se furtava a apreciar com paixão uma luta de boxe. Santiago não falava português perfeitamente, mas também parecia já ter esquecido o espanhol. Dominava línguas praticamente mortas, que aprendera muito novo em suas leituras e viagens pelo mundo. Falava uma fala só dele. Dançava bem, rezava em latim, escrevia lindas poesias, enfim; claramente, uma pessoa especial, um personagem digno de ser documentado.
\end{abstract}

O segundo texto, de Feldman (s/d), dedica vários parágrafos à caracterização de Santiago, corroborando com a visão de Carlos Alberto Mattos (2007b) quando este afirma que "Santiago Badariotti Merlo era um nobre sem estirpe, uma fascinante contradição de classe, um ser trágico. Parecia personagem saído de um filme de Losey ou Visconti", questão também expressa pelo crítico no DocBlog:

\footnotetext{
${ }^{15}$ Neusa Barbosa é coordenadora de conteúdo do Cineweb, site no qual localizamos a crítica analisada, e que tem como proposta reunir jornalistas e críticos de cinema para produção de conteúdo, inclusive para agências de notícias e portais. Também colaboradora em outros veículos, Neusa Barbosa atuou em vários jornais e revistas de grande circulação, sendo autora de livros na área do audiovisual.
} 
Um homem que fantasiou sua vida inteira, à sombra dos lustres e dos arranjos florais de uma aristocracia (ou altíssima burguesia) à qual sonhava pertencer. Para Santiago, a 'casa da Gávea' era o Palazzo Pitti de Florença. Ele, 'senhor dos salões' por 30 anos, simulava seu reino entre acordes de Beethoven, árias de Puccini e lembranças das cores de Giotto. (MATTOS, 2007a)

É essa impressão de Mattos, de sentir-se, enquanto espectador, diante de Santiago como se este fosse um personagem ficcional, e não alguém com existência no mundo histórico, que Feldman enfatiza, descortinando um dos pontos fortes do filme, a imbricação entre realidade e ficção:

E então o filme volta a Santiago, este memorioso e nobre personagem, a um só tempo borgeano e viscontiano. [...] Santiago escolheu viver, ainda que como mordomo, a vida que imaginava. [...] permanecia em seu apartamento como uma espécie de guardião da memória e da perenidade. Lá, mantinha 30 mil páginas datilografadas [...]. Durante mais de 50 anos, Santiago inventariou a aristocracia da humanidade, do Oriente ao Ocidente, de seis mil anos atrás até a modernidade. [...] Construindo propósitos para a sua existência a partir de algo aparentemente inútil, Santiago passou a vida lutando para que seus personagens não fossem esquecidos. Guardava "sua" memória como quem conserva amigos, ainda que distantes. "Não estou só porque estou rodeado dessa gente", ele dizia. Ou ainda: "Eles me compreendem". Nessa solidão tão povoada, era a assumida ficcionalização da vida que the oferecia algum alento, algum sentido. Sentido que inevitavelmente todos nós inventamos, mesmo quando tentamos nos convencer do contrário. $\mathrm{Na}$ lógica do filme, Santiago faz por seus "mortos insepultos", por seus "personagens tétricos", aquilo mesmo que João Moreira Salles faz por Santiago. (FELDMAN, s/d)

Também não há análise nas críticas selecionadas do filme no que toca em seu aspecto de narrativa sobre o homem comum, sua vida cotidiana, ordinária, sobre a vida comum em suas perdas, em sua humildade implorante, que parece se revelar como um tema e um modo centrais no filme, em contraponto com o tipo de vida extraordinário das famílias para as quais Santiago trabalhou e mesmo em sua condição de erudição, enquanto um mordomo de características incomuns.

Santiago, personagem documentado, assim como Salles, também na diegese, apresenta um grau de ficcionalidade que nos leva a refletir sobre a autoficção, uma ficção de si mesmo, um discurso, segundo Diana Klinger (2006: 55), que "se 
situa no interstício entre a 'mentira' e a 'confissão'”, que "não está relacionado com um referente extratextual (como no caso da autobiografia), mas também não está completamente desligado dele" e levanta questões sobre os conceitos de "verdade" e "sujeito". O conceito de autoficção sustenta um vínculo estreito com a memória, uma temática central em Santiago e presente em um trecho representativo da crítica de Luiz Zanin (2007):

Perdemo-nos na rememoração como em um labirinto, conforme nos dizia Proust. E perdermo-nos ainda é a única maneira de recuperar a memória e a nós mesmos. Ela é em parte real, em parte fantasiosa, delirante, construída como sobre as ruínas de alguma civilização extinta. Como saber?

Santiago, com sua "memória prodigiosa", é também narrador, e além de contar suas histórias, colhidas na experiência e transformadas em experiências daqueles que as ouve (BENJAMIN, 1980), exerce um papel de mediador das memórias de Salles, o que está na concepção do próprio documentário e, como vimos também no relato de espectadores do filme, autores de textos críticos mencionados. $\mathrm{O}$ exmordomo de Salles sabia que "narrar histórias é sempre a arte de as continuar contando", e que "esta se perde quando as histórias já não são mais retidas" (BENJAMIN, 1980: 62), e esforçava-se para evitar esta perda, como demonstra o resultado de seu trabalho de copista feito ao longo de tantos anos.

Thiago Camelo (2006) arrisca-se a falar de um "sentimento universal" que emanaria do filme, podendo tocar muitos espectadores: o medo da finitude. Por sua vez, Luiz Zanin (2007) destaca:

Santiago não é apenas o resgate de um personagem, por fascinante que seja. É a prática de um cinema que poderíamos chamar de metafísico, em falta de definição melhor. Ao rondar aquela figura e deixá-la falar do fantasioso mundo aristocrático, o que busca é um pouco da essência da vida, daquilo que a vida, tradução do destino trágico do homem, concede transmitir às imagens e, portanto, ao cinema.

Apesar da leitura das linhas finais do fragmento da crítica de Feldman (s/d), reproduzido anteriormente, apontar para o fato de Salles ter sido capaz de conservar a imagem e a memória de Santiago com seu documentário, as 
motivações do diretor para a realização do filme e, sobretudo, para a retomada do projeto são alvo de julgamento em diversas críticas. A pergunta inicial, de que trata, afinal, Santiago, a busca por um elemento central no documentário, recebe a mesma resposta em alguns textos: diferente do que inferimos a partir do título, o tema central seria o próprio João Moreira Salles.

A visão de Zanin (2007), admitindo tanto Santiago quanto o próprio diretor como personagens centrais, sem, necessariamente, uma hierarquização, numa dimensão que contempla registros de Salles a partir de aspectos pessoais e de sua profissão, parece-nos mais adequada à complexidade do documentário: "Em Santiago, João reflete sobre esse estranho e fascinante personagem que dá título ao filme. Reflete também sobre a própria infância e seu destino de cineasta".

Em entrevista que compõe a crítica de Thiago Camelo (2006), Salles destaca que Santiago é um filme não apenas sobre o ex-mordomo ou somente sobre si mesmo, mas que trata da relação entre ambos, não a relação entre "documentarista e documentado", mas "de patrão e mordomo, de, em última instância, chefe e criado", o que é afirmado, inclusive, na própria fatura fílmica.

A luta de classes é abordada pelos críticos, sobretudo por ter sido evidenciada no próprio documentário a partir da narração. Inácio Araújo (2007) relata que "o que mais se comenta, o que mais o próprio cineasta enfatiza a respeito deste filme é a 'luta de classes' implícita no ato de alguém tomar como personagem seu próprio mordomo".

A postura autocrítica da argumentação de Salles é geralmente valorizada, a exemplo do que encontramos no texto de Camelo (2006): "O que parece ser original aqui é mais a entrega generosa da imagem de si mesmo que João oferece ao espectador. Autocrítica que faz compreender muito sobre a relação do homem com o tempo". Para Cléber Eduardo (s/d), essa é uma discussão central:

João Moreira faz um mea culpa social e cinematográfico, assumindo o erro de seu processo de aproximação com o personagem, carregado de autoritarismo em sua manipulação/intervenção. No entanto, isso é passado, 13 anos atrás. E constatar o deslize é uma forma de constatar uma evolução, nos insinuando que, ao reconhecer o erro, afirma-se um acerto em seu lugar. Santiago não esconde o orgulho de 
constatar uma (auto) transformação entre passado e presente. "Eu era assim, não sou mais", parece-nos dizer.

Daniel Caetano (s/d) também aborda a temática: "Santiago se apresenta como um ritual de mea culpa, mas o que o filme traz de mais triste é que esta autocrítica diante do personagem outrora desrespeitado parece servir apenas como estilo retórico".

Carlos Alberto Mattos (2007a) revela que "durante um bom tempo, João Moreira Salles confessava não saber o que fazer com filme tão pessoal e inusitado. Temia que a expiação pública fosse interpretada como um ato de vaidade". Isso de fato ocorreu, como vemos na avaliação de Feldman (s/d), que se refere à luta de classes apresentando a autocrítica expressa pelo narrador como um discurso construído de forma consciente, com a intenção de suscitar a discussão, mas num movimento que gera uma reação positiva e o esvaziamento da crítica do outro diante da crítica a si mesmo:

Equivoca-se quem reduz a mediação proposta pelo filme a uma tensão de classe, que se daria entre o controle e a dominação de Salles (diretor e patrão) e o servilismo de Santiago (personagem e empregado). Essa é uma autocrítica assumida pelo próprio Salles, por meio de sua narração, em um gesto de inegável franqueza, por um lado, mas também de habilidosa estratégia. Afinal, toda impiedosa autocrítica é uma forma de blindagem contra a própria crítica alheia. E toda impiedosa autocrítica acaba por revelar-se como um atestado de extraordinária inteligência, profunda honestidade e, não há jeito, extrema vaidade.

\section{Os diferentes papéis de Salles: documentando a si mesmo}

Nas críticas, é possível perceber com clareza uma dificuldade, ou mesmo desinteresse, da maioria de seus redatores em fazer com que o leitor atente para a necessária diferenciação entre as várias posições assumidas por João Moreira Salles na relação com seu documentário.

Em primeiro lugar, o entendimento de Salles sobre o personagem criado a partir da seleção e montagem, que é exposto para o público na tela, e o sujeito existente no mundo histórico, já norteia uma distinção fundamental, que, 
novamente, leva-nos à autoficcionalidade, ao personagem documentado enquanto construção, fabricado a partir de escolhas, da bricolagem de determinados elementos e da exclusão de outros tantos.

Em texto teórico, Salles (2005: 63) afirma que "para um documentarista, a realidade que interessa é aquela construída pela imaginação autoral, uma imaginação que se manifesta tanto no momento da filmagem como no processo posterior de montagem" e defende a definição de John Grierson de documentário enquanto "tratamento criativo da realidade", destacando que "os documentários não pretendem reproduzir o real, mas falar sobre ele" (SALLES, 2005: 66). Para Bill Nichols (2005: 30), "a ideia de representação é fundamental para o documentário" e "o ato de filmar altera a realidade que pretende representar" (NICHOLS, 2005: 31).

Partindo da ideia de representação trazida pelo autor, voltamos ao texto de Salles (2005: 67), que esclarece: "documentários não são exatamente sobre os outros, mas sobre como documentaristas mostram os outros. A representação de qualquer coisa é a criação de outra coisa. No caso, essa outra coisa criada é um personagem" (grifo do autor). Aponta ainda um paradoxo do realizador do documentário em que reside o que o diretor chama de "a verdadeira questão do documentário", que seria a sua natureza ética: "potencialmente, os personagens são muitos, mas a pessoa filmada, não obstante suas contradições, é uma só" (SALLES, 2005: 68) e "o que nós documentaristas temos de lembrar o tempo todo é que a pessoa filmada possui uma vida independente do filme" (SALLES, 2005: 70).

A partir dessa questão ética expressa por Salles, entendemos que se colocar no lugar de um personagem documentado, ou seja, documentar a si mesmo, é uma forma de também vivenciar, em outra posição, o que se passa com as pessoas que estiveram diante de sua câmera e transformaram-se em um personagens moldados por ele, a partir de escolhas de captação, roteiro e montagem.

Enquanto personagem, já é necessário ponderarmos sobre a representação de momentos e instâncias narrativas distintas: o diretor de 1992, que aparece apenas 
uma vez em cena, mas do qual ouvimos a voz extracampo em diversas oportunidades, conduzindo a entrevista com Santiago, o narrador-personagem, identificado na diegese como o documentarista já em um tempo diverso, após a retomada do projeto em 2005, e o Salles menino, da história de infância. Nenhuma dessas faces de Salles é o indivíduo João Moreira Salles do universo extrafílmico, e, sim, a representação de fragmentos de si, selecionados e trabalhados para atender a um fim e causar no espectador determinada impressão.

A maioria dos textos não reflete essas distinções, o que observamos, por exemplo, na crítica de Amaral (s/d): "no documentário, João chega a afirmar que a ideia no papel era boa, mas que, na película, não estava em consonância com aquilo outrora pensado" e na de Carlos Alberto Mattos (2007a, grifo nosso):

\footnotetext{
Salles reexamina à distância o conteúdo de certos planos, comenta os métodos utilizados. Impiedoso consigo mesmo, põe a nu as interferências de quem se julgava "dono" do personagem. Mostra as interrupções, as repetições, a brutalidade das claquetes, a encenação constrangedora. Deixa ouvir sua voz comandando o exmordomo com certa arrogância, numa situação em que diretor e patrão se confundiam inapelavelmente. É um gesto de auto-exposição em vários sentidos, de que o discreto e reservado Salles não parecia capaz.
}

Dentre as selecionadas, apenas duas críticas destacam-se pela tentativa de levar os leitores à reflexão sobre a existência desses diversos papéis. Daniel Caetano (s/d), ainda no primeiro parágrafo, destaca que "o personagem narradorautor se culpa pela forma com que arquitetava um documentário". Mais à frente, Caetano continua usando terminologia específica para distinguir as diversas funções de Salles na narrativa, mas se perde na descrição: "todo o discurso do filme passa a ter um tom próximo do religioso, com a criação de dois momentos do narrador-autor - manipulador e cheio de soberba no passado e agora capaz de reconhecer e expor a todos os seus próprios erros". Sente-se a necessidade de uma diferenciação entre o Salles enquanto personagem em cena, mencionado no trecho como "cheio de soberba no passado" e o narrador, que se encontra em outro tempo do discurso, em outro nível narrativo (GENETTE, 1995), e assume forma diversa de representação no contexto documental. 
Apenas na crítica de Feldman (s/d), encontramos uma diferenciação coerente, desde a abertura, entre Salles e o narrador do documentário: "Em Santiago [...] a primeira palavra que ouvimos do documentarista João Moreira Salles (e não do narrador do filme) é um inequívoco 'não!" (grifo nosso). O texto segue demarcando claramente as diferentes posições assumidas pelo documentarista, a exemplo de outro trecho, sobre a autocrítica ("Salles sabe que essa questão, ao ser explicitada pelo discurso organizador, é de certa forma também esvaziada"), e, adiante, destacando o distanciamento entre o diretor e Santiago:

\footnotetext{
Ao questionar seus artifícios, imposturas, opções e, sobretudo, ao questionar a distância que se instala entre documentarista e personagem, ou entre patrão e empregado (como o narrador mesmo admite ao final), a narração autorreflexiva organiza e roteiriza a experiência, emitindo, do presente, um sentimento de mundo, sobre o passado e, de certo, sobre o futuro. (FELDMAN, s/d)
}

\section{Conclusão}

Jacques Aumont e Michel Marie (2008: 12) apontam na crítica a função de "informar, avaliar, promover". Diferenciam a atividade de crítica jornalística, realizada nos diários e semanários, com o intuito de informar e ofertar um juízo de apreciação, e a crítica realizada para publicações especializadas, nas quais o critério de atualidade não desempenha papel determinante, havendo uma liberdade maior para escolha da obra que será analisada.

Os autores percebem o "bom crítico" como "um analista, mesmo que potencialmente, e que uma das suas qualidades é precisamente a atenção para os detalhes, associada a uma forte capacidade interpretativa" (2008: 11), enquanto "pedagogo do prazer estético, que se esforça por partilhar a riqueza da obra com o maior público possível" (2008: 13).

Esses "detalhes" da obra são revelados a partir da abordagem a que se propõe cada analista, considerando as diferentes possibilidades que o filme encerra, entendido por Aumont e Marie (2008: 10) enquanto "obra artística autônoma, suscetível de engendrar um texto (análise textual) que fundamenta os seus significados em estruturas narrativas (análise narratológica) e em dados 
visuais e sonoros (análise icônica) produzindo um efeito particular no espectador" (AUMONT; MARIE, 2008: 10). Nas críticas selecionadas, aspectos variados são focados, como a narração, a construção da imagem, aspectos do gênero documental e a relação entre o documentarista e o seu personagem.

Esse alargamento de compreensão que pode ser provocado pela crítica cinematográfica, em especial no espectador comum, demostra a importância da circulação de textos de natureza analítica, servindo aos leitores enquanto espaço de formação, intensificação da experiência espectatorial, despertando a reflexão mais apurada sobre as obras cinematográficas e retroalimentando o debate no âmbito da própria crítica fílmica.

Antoine de Baecque (2010: 32) entende que "o cinema exige que se fale dele. As palavras que o nomeiam, os relatos que o narram, as discussões que o fazem reviver - tudo isso modela sua existência real" e "ir ao cinema, assistir aos filmes, isso não se compreende sem esse desejo de prolongar sua experiência pela fala, pela conversa, pela escrita. Cada uma dessas rememorações confere verdadeiro valor ao filme" (BAECQUE, 2010: 33).

Os diferentes olhares discutidos nas críticas selecionadas sobre Santiago postos em diálogo nos dão acesso a novos sentidos, e diversos entre si, suscitados pela obra, que se somam, confrontam-se, complementam-se, constituindo um mosaico de visões dadas por diferentes filtros forjados a partir da constituição particular de cada sujeito interpretante, de seu lugar de fala, determinado pelo veículo a partir do qual escreve, por suas condições de produção e espectação fílmica, seu repertório, sua formação discursiva.

Abarcando uma gama variada de veículos, meios da grande imprensa, revistas especializadas em cinema e sites, consideramos que os textos analisados, vistos em conjunto, constituem um escopo interessante a respeito do esforço analíticointerpretativo da crítica, podendo gerar tensionamentos, esclarecimentos e percepção ampliada sobre o documentário de João Moreira Salles. 


\section{Referências:}

AUMONT, Jacques; MARIE, Michel. A análise do filme. Lisboa: Texto \& Grafia, 2013.

BAECQUE, Antonio. Cinefilia: invenção de um olhar, história de uma cultura. São Paulo: Cosac Naify, 2010.

BAMBA, Mahomed. "Zizek em The pervert's guide to cinema: um caso de leitura fílmica performativa e de 'recepção criativa". XIII Estudos de Cinema e Audiovisual Socine, v. 1, São Paulo: Socine, 2012. 250-262.

BAZIN, André. O cinema: ensaios. São Paulo: Brasiliense, 1991.

BENJAMIN, Walter. "O narrador". In: BENJAMIN, Walter. et al. Textos escolhidos. Trad. José Lino Grünnewald. São Paulo: Abril Cultural, 1980. 57-74.

GENETTE, Gérard. O discurso da narrativa. 3. ed. Trad. Fernando Cabral Martins. Lisboa: Vega, 1995.

KLINGER, Diana Irene. "A escrita de si (o retorno do autor)". In: KLINGER, Diana Irene. Escritas de si, escritas do outro: autoficção e etnografia na narrativa latinoamericana contemporânea. 2006. Tese (doutorado). Universidade do Estado do Rio de Janeiro, Instituto de Letras, Rio de Janeiro. 16-67.

JOLY, Martine. A imagem e sua interpretação. Lisboa: Edições 70, 2002.

LINS, Consuelo; MESQUITA, Cláudia. Filmar o real: sobre o documentário brasileiro contemporâneo. 2. ed.

Rio de Janeiro: Zahar, 2011.

LINS, Consuelo. "O ensaio no documentário e a questão da narração em off". Trabalho apresentado ao XVI Encontro Anual da Compós - GT Fotografia, Cinema e Vídeo. Curitiba, PR, 2007.

MASCARELLO, Fernando. "Mapeando o inexistente: os estudos de recepção cinematográfica, por que não interessam à universidade brasileira?". UNIrevista v. 1 , n. 3, jul. 2006, 1-12.

MASCARELLO, Fernando. "Notas para uma teoria do espectador nômade". Novos Olhares, São Paulo: Escola de Comunicação e Artes da USP, n. 7, 1. sem. 2001, 4-20.

NICHOLS, Bill. Introdução ao documentário. Trad. Mônica Saddy Martins. Campinas: Papirus, 2005. 
PENAFRIA, Manuela. "Análise de filmes - conceitos e metodologias". Trabalho apresentado ao VI Congresso SOPCOM, 2009. Disponível em: <http://www.bocc.ubi.pt/pag/bocc-penafria-analise.pdf $>$. Acessado em: 10 de abril de 2013.

PUCCI JR., Renato Luiz. "Adaptação televisiva e esquemas cognitivos: o caso de Capitu”. In: BORGES, Gabriela; PUCCI JR., Renato Luiz; SOBRINHO, Gilberto Alexandre (Orgs.). Televisão: formas audiovisuais de ficção e de documentário. 1. ed. Campinas, Faro, São Paulo: CIAC \& Socine, 2012, v. 2, 29-43.

SALLES, João Moreira. "A dificuldade do documentário". In: MARTINS, José Souza; ECKERT, Cornelia; NOVAES, Sylvia Caiuby (Orgs.). O imaginário e o poético nas ciências sociais. Bauru: EDUSC, 2005. 57-71.

STAM, Robert. Introdução à teoria do cinema. Trad. Fernando Mascarello. Campinas: Papirus, 2003.

VANOYE, François; GOLIOT-LÉTÉ, Anne. Ensaios sobre análise fílmica. Trad. Marina Appenzeller. Campinas: Papirus, 1994.

\section{Críticas consultadas:}

AMARAL, Leonardo. Santiago. Revista eletrônica Filmes Polvo. s/d. Disponível em: <http://filmespolvo.com.br/site/artigos/cinetoscopio/549>. Acessado em: 13 de outubro de 2012.

ARAÚJJ, Inácio. Salles usa mordomo como espelho e faz um ótimo filme sobre si mesmo. Folha de São Paulo llustrada. São Paulo, 24 de agosto de 2007. Disponível em: <http://www1.folha.uol.com.br/fsp/ilustrad/fq2408200709.htm>. Acessado em: 13 de outubro de 2012.

BARBOSA, Neusa. [Sem título]. Cineweb. Publicado em: 23 de agosto de 2007. Disponível em: <http://cineweb.com.br/filmes/filme.php?id_filme=2197>. Acessado em: 10 de outubro de 2012.

CAETANO, Daniel. [Sem título]. In: Revista Contracampo. s/d. Disponível em: <http://www.contracampo.com.br/88/critsantiago.htm>. Acessado em: 10 de outubro de 2012.

CAMELO, Thiago. O filme e o filme de João Moreira Salles. Overmundo. Publicado em: 11 de dezembro de 2006. Disponível em:

$<$ http://www.overmundo.com.br/overblog/o-filme-e-o-filme-de-joao-moreirasalles>. Acessado em: 10 de outubro de 2012. 
EDUARDO, Cléber. Subjetividade mediada: entre a classe social e a família universal. Revista $\quad$ Cinética. $\mathrm{s} / \mathrm{d}$. Disponível em: <http://www.revistacinetica.com.br/santiagocleber.htm>. Acessado em: $10 \mathrm{de}$ outubro de 2012.

FELDMAN, Ilana. Santiago sob suspeita. UOL / Revista Trópico. s/d. Disponível em: <http://p.php.uol.com.br/tropico/html/textos/2907,1.shl>. Acessado em: 13 de outubro de 2012.

MATTOS, Carlos Alberto. Com uma certa desconfiança. Site Críticos.com.br. Publicado em: 24 de agosto de 2007b. Disponível em: <http://criticos.com.br/?p=1295\&cat=1 >. Acessado em: 03 de abril de 2013.

MATTOS, Carlos Alberto. O senhor dos salões. Site Globo Online. DocBlog. Publicado em: 23 de março de 2007a. Disponível em: <http://oglobo.globo.com/blogs/docblog/posts/2007/03/23/o-senhor-dossaloes-51990.asp>. Acessado em: 03 de abril de 2013.

ORICCHIO, Luiz Zanin. E agora, Santiago? In.: O Estado de São Paulo / Blog Luiz Zanin - Cinema, cultura \& afins. Publicado em: 24 de agosto de 2007. Disponível em: <http://blogs.estadao.com.br/luiz-zanin/e-agora-santiago/>. Acessado em: 13 de outubro de 2012.

\section{Filmografia trabalhada:}

Santiago (2007), de João Moreira Salles.

\section{Filmografia mencionada:}

Capitu (2008, Globo), de Luiz Fernando Carvalho.

Entreatos (2004), de João Moreira Salles.

Filmefobia (2008), de Kiko Goifman.

Jogo de cena (2007), de Eduardo Coutinho.

Últimas conversas (2015), de Eduardo Coutinho, finalizado por João Moreira Salles. 